\title{
A STUDY ON EFFECT OF OMENTIN IN GLUCOSE AND LIPID METABOLISM IN NORMAL AND DIABETIC RATS.
}

\author{
Ahmad B. Abd-Allah, Mohammed S. Zamzam, Azza A. Megahed, Safya E. Esmaeel. \\ Physiology department, Faculty of medicine, Zagazig University.
} \begin{abstract}
Background and study aim: Previous works have revealed that adipose tissue functions as an endocrine organ, producing a variety of adipokines. These so-called adipokines play important roles in metabolic homeostasis, and when their production is not properly regulated, they can contribute to metabolic diseases. Omentin is a novel adipokine secreted from visceral omental fatand others. Evidence suggests that omentin is one of the factors involved in the complex network that controls insulin resistance, obesity and diabetes. We aimed to evaluate the effects of in vivo administration of omentinon glucose and lipid metabolism in normal conditions and in experimentally induced type 2 diabetes mellitus.
\end{abstract}

Material and Methods: In this work, 60 adult male white albino rats were divided into 6 equal groups each group contains 10 animals. These groups are control, omentin injected, obese/diabetic, obese/diabetic omentin injected, obese/diabetic insulin injected and obese/diabetic insulin and omentin injected groups. The effect of omentin on metabolic parameters was reflected by analysis of fasting serum glucose, insulin and HOMA IR and HOMA $\beta$. Also, full analysis for lipid profile including total cholesterol, LDL-cholesterol, triglycerides and HDL-cholesterol was performed. Parallel to analytic studies, anthropometric measures were obtained in the form of body mass index (BMI) and waist circumference.

Results: There were significant decreases in serum levels of glucose in obese/diabetic omentin injected and obese/diabetic insulin and omentin injected group $(\mathrm{P}<0.001, \mathrm{P}<0.001$ respectively). But, this effect was insignificant in omentin injected animals when compared with control. Likewise, there were significant decreases in HOMA IR in obese/diabetic omentin injected and obese/diabetic insulin and omentin injected group $(\mathrm{P}<0.001, \mathrm{P}<0.001$ respectively). In addition, there were significant increases in HOMA $\beta$ in obese/diabetic omentin injected and obese/diabetic insulin and omentin injected group $(\mathrm{P}<0.001, \mathrm{P}<0.001$ respectively).

In obese/diabetic animals, injection of omentin resulted in a significant decrease in total cholesterol, LDL and triglycerides, together with a significant increase in HDL.

Conclusion: We can conclude that, the insulin sensitizer effect of omentin improves both glucose tolerance and dyslipidemia in cases of type 2 diabetes but not in the normal conditions.

Key words: omentin, diabetes, obesity, insulin, lipid, glucose.

\section{INTRODUCTION}

$\mathbf{T}$ he perspective of adipose tissue as merely a fat depot has changed in recent times. Focus is now being laid on the metabolic and inflammatory functions of the adipose tissue which is modulated through adipokines ${ }^{[1]}$.

Like an endocrine organ, adipose tissue secretes a variety ofadipokines, including omentin which is a novel fat depot-specificadipokine that was identified from a cDNA library fromvisceral omental adipose tissue by ${ }^{[2]}$.

In humans omentin-1and omentin-2 genes are localized adjacent to each other in the1q22-q23 chromosomal region, which has been previously linkedto type 2 diabetes ${ }^{[3]}$. Omentin-1 is the major circulating isoform and its plasma and visceral adipose tissue gene expressionlevels are inversely correlated with body mass index (BMI), waistcircumference, leptin levels and insulin resistance, while its levels arepositively correlated with adiponectin and high-density lipoprotein levels. Furthermore, circulating omentin-1 concentrationsincrease after weight loss ${ }^{[4]}$.

\section{AIM OF WORK}

Theaim of this study is to clarify the in-vivo effects of omentin administration on glucose and lipid metabolism in experimental animals both in normal conditions and in experimentally induced type 2 diabetes mellitus.

\section{MATERIAL AND METHODS}

This present study was conducted in the physiology department, faculty of medicine, Zagazig university during the period from November 2011 to January 2014.

All these material and methods are approved by the "Institutional Research Board" of faculty of medicine in Zagazig university, Egypt.

60 adult male white albino rats were divided into 6 equal groups each group contains 10 animals. These groups are control, omentin injected, obese/diabetic, obese/diabetic omentin injected, obese/diabetic insulin injected and obese/diabetic insulin and omentin injected groups.

Omentin was supplied as omentin recombinant from E.coli. BioVision - Analytica, catalog No. 4925 - 10 . Product of USA. 
In omentin injected groups, omentin was injected intraperitoneally once daily $($ dose $=100 \mathrm{ng}, \mathrm{ml})$ ${ }^{[5]}$ for 7 days.

In all animals the following parameters were measured:

- Estimation of fasting serum insulin level [6].

- Estimation of fasting serum glucose level [7].

- Calculation of homeostasis model assessment (HOMA) and $\beta$-cell function (HOMA- $\beta$ ). [HOMA-IR = insulin $(\mu \mathrm{U} / \mathrm{mL}) \times$ glucose $(\mathrm{mmol} / \mathrm{L}) / 22.5]$ and $\beta$-cell function [HOMA- $\beta=20 \mathrm{x}$ insulin $(\mu \mathrm{U} / \mathrm{mL}) /($ glucose $(\mathrm{mmol} / \mathrm{L})-3.5)]^{[8]}$.

- Estimation of serum total cholesterol levels ${ }^{[7]}$.

- Estimation of serum HDL-cholesterol ${ }^{[9]}$.

- Estimation of serum triglycerides ${ }^{[\mathbf{1 0 ]}}$.

- Determination of low density lipoprotein cholesterol ${ }^{[11]}$.

- Calculating body mass index (BMI) ${ }^{[12]}$.

Statistical analysis: comparisons between means of several groups were done by one way Anova ( $\mathrm{F}$ test) and t-test when there was a significance difference between means. $P$ value was considered significant when less than 0.05 .

\section{RESULTS}

Table 1: Serum changes, HOMA and anthtopometric measures in all studied groups.

\begin{tabular}{|c|c|c|c|c|c|c|c|}
\hline & & $\begin{array}{l}\text { Control } \\
\text { (I) }\end{array}$ & $\begin{array}{l}\text { Omentin } \\
\text { treated } \\
\text { (II) }\end{array}$ & $\begin{array}{c}\text { Obese/diabeti } \\
\text { c } \\
\text { (IIIa) }\end{array}$ & $\begin{array}{c}\text { Obese/diabeti } \\
\text { c } \\
\text { omentin } \\
\text { treated } \\
\text { (IIIb) }\end{array}$ & $\begin{array}{c}\text { Obese/diabeti } \\
\text { c } \\
\text { insulin } \\
\text { treated } \\
\text { (IIIc) }\end{array}$ & $\begin{array}{c}\text { Obese/diabet } \\
\text { ic } \\
\text { insulin \& } \\
\text { omentin } \\
\text { treated } \\
\text { (IIId) }\end{array}$ \\
\hline \multirow{2}{*}{$\begin{array}{l}\text { Glucose } \\
(\mathrm{mmol} / \mathrm{L})\end{array}$} & \multirow[t]{2}{*}{$\bar{X} \pm \mathbf{S D}$} & $7 \pm 0.36$ & $6.65 \pm .63$ & $15.53 \pm 0.16$ & $10.78 \pm 0.42$ & $7.37 \pm .54$ & $5.96 \pm .53$ \\
\hline & & \multicolumn{2}{|c|}{$\mathrm{P}>0.05$} & \multicolumn{2}{|c|}{$\mathrm{P}<0.001 * *$} & \multicolumn{2}{|c|}{$\mathrm{P}<0.001 * *$} \\
\hline \multirow{2}{*}{$\begin{array}{l}\text { Insulin } \\
(\mu \mathrm{IU} / \mathrm{ml})\end{array}$} & \multirow{2}{*}{$\bar{X} \pm \mathbf{S D}$} & $10.3 \pm .59$ & $9.93 \pm .5$ & $12.15 \pm .19$ & $11.28 \pm .41$ & $10.31 \pm .62$ & $9.77 \pm .69$ \\
\hline & & \multicolumn{2}{|c|}{$\mathrm{P}>0.05$} & \multicolumn{2}{|c|}{$\mathrm{P}<0.001 * *$} & \multicolumn{2}{|c|}{$\mathrm{P}<0.05 *$} \\
\hline \multirow[t]{2}{*}{ HOMA IR } & \multirow{2}{*}{$\overline{\mathrm{X}} \pm \mathbf{S D}$} & $3.2 \pm .26$ & $2.93 \pm .39$ & $8.38 \pm .3$ & $5.41 \pm .38$ & $3.38 \pm .42$ & $2.58 \pm .32$ \\
\hline & & \multicolumn{2}{|c|}{$\mathrm{P}<0.05 *$} & \multicolumn{2}{|c|}{$\mathrm{P}<0.001 * *$} & \multicolumn{2}{|c|}{$\mathrm{P}<0.001 * *$} \\
\hline \multirow[t]{2}{*}{ HOMA $\beta$} & \multirow[t]{2}{*}{$\overline{\mathrm{X}} \pm \mathrm{SD}$} & $59.39 \pm 7.37$ & $\begin{array}{c}64.76 \pm 10.0 \\
4\end{array}$ & $20.24 \pm 1.24$ & $31.01 \pm 1.35$ & $53.86 \pm 5.6$ & $83.53 \pm 22.59$ \\
\hline & & \multicolumn{2}{|c|}{$P>0.05$} & \multicolumn{2}{|c|}{$\mathrm{P}<0.001 * *$} & \multicolumn{2}{|c|}{$\mathrm{P}<0.001 * *$} \\
\hline \multirow{2}{*}{$\begin{array}{l}\text { Total } \\
\text { cholesterol } \\
(\mathrm{mg} / \mathrm{dl})\end{array}$} & \multirow[t]{2}{*}{$\overline{\mathrm{X}} \pm \mathrm{SD}$} & $169.2 \pm 17.7$ & $\begin{array}{c}156.2 \pm 19.1 \\
7\end{array}$ & $278.9 \pm 6.1$ & $192.4 \pm 16.54$ & $193.6 \pm 22.59$ & $148.3 \pm 8.59$ \\
\hline & & \multicolumn{2}{|c|}{$P>0.05$} & \multicolumn{2}{|c|}{$\mathrm{P}<0.001 * *$} & \multicolumn{2}{|c|}{$\mathrm{P}<0.001 * *$} \\
\hline \multirow{2}{*}{$\begin{array}{l}\text { Triglycerid } \\
\text { es } \\
(\mathrm{mg} / \mathrm{dl})\end{array}$} & \multirow[t]{2}{*}{$\overline{\mathrm{X}} \pm \mathbf{S D}$} & $98.4 \pm 15.88$ & $96.2 \pm 9.53$ & $163.9 \pm 18.08$ & $148.8 \pm 15.8$ & $101.4 \pm 13.2$ & $92.3 \pm 9.69$ \\
\hline & & \multicolumn{2}{|c|}{$\mathrm{P}>0.05$} & \multicolumn{2}{|c|}{$\mathrm{P}<0.05 *$} & \multicolumn{2}{|c|}{$\mathrm{P}<0.05 *$} \\
\hline \multirow[t]{2}{*}{$\begin{array}{l}\text { LDL } \\
\text { (mg/dl) }\end{array}$} & \multirow[t]{2}{*}{$\overline{\mathrm{X}} \pm \mathbf{S D}$} & $\begin{array}{c}88.52 \pm 14.5 \\
8\end{array}$ & $\begin{array}{c}78.26 \pm 18.8 \\
8\end{array}$ & $201.12 \pm 8.41$ & $107.54 \pm 16.76$ & $114.42 \pm 20.83$ & $65.94 \pm 11.28$ \\
\hline & & \multicolumn{2}{|c|}{$\mathrm{P}>0.05$} & $\mathrm{P}<0$. & $01 * *$ & $\mathrm{P}<0$ & $1 * *$ \\
\hline \multirow{2}{*}{$\begin{array}{l}\text { HDL } \\
(\mathrm{mg} / \mathrm{dl})\end{array}$} & \multirow[t]{2}{*}{$\overline{\bar{X}} \pm \mathrm{SD}$} & $61 \pm 3.52$ & $58.7 \pm 4.52$ & $45 \pm 3.68$ & $55.1 \pm 4.17$ & $58.9 \pm 4.99$ & $63.9 \pm 4.43$ \\
\hline & & $\mathrm{P}>$ & .05 & $\mathrm{P}<0$. & $01 * *$ & $\mathrm{P}<$ & $5 *$ \\
\hline BMI & $\overline{\mathrm{X}} \pm \mathrm{SD}$ & $.58 \pm .03$ & $.56 \pm .05$ & $0.84 \pm .06$ & $.83 \pm .05$ & $.81 \pm .07$ & $.81 \pm .05$ \\
\hline & & $\mathrm{P}>$ & .05 & $\mathrm{P}>$ & .05 & $\mathrm{P}>$ & \\
\hline WC & $\overline{\mathrm{X}} \pm \mathrm{SD}$ & $12.33 \pm .5$ & $12.39 \pm .52$ & $14.32 \pm .79$ & $14.26 \pm .64$ & $14.11 \pm .6$ & $14.05 \pm .33$ \\
\hline & & $\mathrm{P}>$ & & $\mathrm{P}>$ & .05 & & \\
\hline
\end{tabular}

There were significant decreases in serum levels of glucose in obese/diabetic omentin injected and obese/diabetic insulin and omentin injected group
$(\mathrm{P}<0.001, \mathrm{P}<0.001$ respectively). But, this effect was insignificant in omentin injected animals when compared with control. Likewise, there 
were significant decreases in HOMA IR in obese/diabetic omentin injected and obese/diabetic insulin and omentin injected group $(\mathrm{P}<0.001, \mathrm{P}<0.001$ respectively $)$. In addition, there were significant increases in HOMA $\beta$ in obese/diabetic omentin injected and obese/diabetic insulin and omentin injected group ( $\mathrm{P}<0.001, \mathrm{P}<0.001$ respectively).

\section{DISCUSSION}

Starting by the metabolic corner stone, glucose, this study revealed a significant decrease $(\mathrm{p}<$ 0.001 ) in fasting levels of serum glucose after injection of omentin in the obese/diabetic animals. Also, there was a significant decrease $(p<0.001)$ in fasting levels of serum glucose after injection of omentin in the obese/diabetic insulin treated animals. Accordingly, insulin-mimetic, insulinlike or insulin sensitizer effect of omentin might be assumed.

In agree with Shan et al ${ }^{[13]}$,omentininduced activation of Akt (phosphatidyl-inositol-3 kinase downstreameffector). In the same field, previous study revealed that, circulating omentinlevels were lower in type 2 diabetes mellitus versus controls. So, decreases in omentinlevels could contribute to the induction of cardiovascular dysfunction in type 2 diabetes mellitus ${ }^{[14]}$.

Obviouslink between serum levels of omentin and obesity was in the form of significant decreases of omentin serum levels obesity. Accordingly, it has been suggested that omentin act as insulinsensitizers/insulin-mimetics. But, it is still difficult to assess clearly the influence of omentin on the pathogenesis of obesity ${ }^{[15]}$.

Side by side to the decreased fasting levels of serum glucose in obese/diabetic groups, results of the current study came also with a significant decrease $(p<0.001)$ in the fasting levels of serum insulin in obese/diabetic groups after injection by omentin. In addition, there was also a similar significant decrease $(p<0.05)$ in the fasting levels of serum insulin in obese/diabetic insulin treated group after injection by omentin.

This finding is in agreement with the reported effects of hyperinsulinemic inhibition of omentinproduction in healthy subjects. Thus, insulin-downregulated omentinproduction could be behind the inverse relationship between circulating omentinand obesity ${ }^{[16]}$.

Taking in consideration the reflections of fasting glucose levels on the fasting insulin levels, Derosa et al ${ }^{[17]}$ found a similar results but for different substance. They found that, olmesartan/amlodipine combination, but not amlodipine, decreased fasting plasma glucose after 12months. Olmesartan/amlodipine combination better decreased fasting plasma insulin and HOMA IR index. So, other than to be more effective in reducing fasting blood glucose, olmesartan/amlodipine single pill combination gave also a major increase of insulin sensitivity. An impressing finding of our study was that, there was a significant decrease $(\mathrm{p}<0.001)$ in the HOMA IR index for insulin resistance in the obese/diabetic group after injection of omentin. As well, there was a significant decrease $(p<$ 0.001) in the HOMA IR index for insulin resistance in the obese/diabetic insulin treated group after injection of omentin. So, the current study revealed that, omentin produced an enhancement of insulin sensitivity together with an improvement of glucose tolerance in the pathological conditionin the form of obese/diabetic group.

As regard the HOMA $\beta$ index for $\beta$ cells function, our study exposed that, there was a significant increase $(p<0.001)$ in the HOMA $\beta$ index for $\beta$ cells function in the obese/diabetic group after injection of omentin. As well, there was a significant increase $(p<0.001)$ in the HOMA $\beta$ index for $\beta$ cells function in the obese/diabetic insulin treated group after injection of omentinthe. This speculated anti-diabetic property of omentin was shown by many study groups but for different oral anti-diabetic agents. Derosa et al ${ }^{[18]}$ showed that, treatment with sitagliptin + metformin was more effective than placebo + metformin in improving glycemic control, the HOMA-IR and the glucagon level and increasing the HOMA- $\beta$ and all $\beta$-cell measurements.

In another study, vildagliptin+metformin were more effective than placebo+metformin in reducing body weight and BMI, glycemic control, HOMA-IR, glucagon and insulin resistance measurements. Vildagliptin+metformin gave also a better increase of HOMA- $\beta$, and of all $\beta$-cell parameters. Vildagliptin, in addition to metformin, proved to be effective in improving $\beta$ cell function and in reducing insulin resistance measurements ${ }^{[19]}$

Collecting the previous data together, there may be a resemblance between omentin and oral antidiabetic agents regarding the effects on HOMA IR and HOMA $\beta$, this similarity may be a leading point of view in further studies on omentin and 
may raise the name of omentin in the field of management of type 2 diabetes mellitus.

In conjunction with glycemic control, lipid profile stands in the same priority. The results of the present study revealed that, there were insignificant changes in omentin treated group versus control group regarding serum levels of cholesterol, LDL-cholesterol, triglycerides and HDL-cholesterol. Whereas, in obese/diabetic group, there were significant decreases in the serum levels of cholesterol, LDL-cholesterol and triglycerides $(\mathrm{p}<0.001, \mathrm{p}<0.001$ and $\mathrm{p}<0.05$ respectively) after treatment with omentin. Furthermore,in obese/diabetic insulin treated group, there were significant decreases in the serum levels of cholesterol, LDL-cholesterol and triglycerides $(\mathrm{p}<0.05, \mathrm{p}<0.001$ and $\mathrm{p}<0.05$ respectively) after treatment with omentin.

On the other hand, there was insignificant change in serum levels of HDL-cholesterol in omentin treated group versus control group. Even as, in obese/diabetic group, there was a significant increase in the serum levels of HDL-cholesterol ( $p<$ 0.001) after treatment with omentin. Besides,in obese/diabetic insulin treated group, there was a significant increases in the serum levels of HDL-cholesterol ( $p<0.05)$ after treatment with omentin.

Likewise, omentin was found to be correlated significantly with high-density lipoprotein cholesterol and inversely with glucose and triglycerides ${ }^{[20]}$.

Furthermore, a reduction of plasma omentin levels significantly correlated with an increase in the mean number of metabolic risk factors such as increased waist circumference, dyslipidemia, high blood pressure and glucose intolerance. Circulating omentin levels negatively correlated with the multiplicity of metabolic risk factors, suggesting that omentin acts as a biomarker of metabolic disorders ${ }^{[21]}$.

Consequently, the hypothetical advantageous effect of omentin was intensified in our study by the investigated direct effect of omentin on the serum lipid profile in the form of reduction of cholesterol, LDL-cholesterol and triglycerides cooperatively with elevation of HDL-cholesterol. In view of that, omentin may get hold of more beneficial effects on dyslipidemia beside glucose intoleranceespecially in diabetic conditions.

Regarding the anthropometric measurements, our study revealed that, there were insignificant changes in neither body mass index nor waist circumference after injection of omentin in different studied groups. Despitethe negative correlations between omentin levels and body mass index, but, omentin may still has no direct effect on the body mass index and other anthropometric measures. This may be due to short duration of injection. Hence, further studies are required to clarify the effect of long term administration of omentin on anthropometric measures.

\section{CONCLUSION}

The insulin sensitizer effect of omentin improves both glucose tolerance and dyslipidemia in cases of type 2 diabetes but not in the normal conditions. Further studies are required to clarify the effect of omentin in type 1 diabetes and also its effect during long term administration.

\section{FUNDING}

None.

\section{CONFLICTS OF INTEREST}

None.

\section{ETHICAL APPROVAL}

The study was performed in accordance with the ethical standards of the "Institutional Research Board" of faculty of medicine in Zagazig university, Egypt.

\section{REFERENCES}

[1] Jaikanth C, Gurumurthy P, Cherian KM, Indhumathi T. (2013): Emergence of omentin as a pleiotropic adipocytokine. Exp Clin Endocrinol Diabetes. 121(7):377-83. doi: 10.1055/s-00331345123.

[2] Yang R.Z, Xu A, Pray J, Hu H, Jadhao S, Hansen B. (2003): Cloning of omentin, a new adipocytokine from omental fat tissue in humans. Diabetes. 52: p. A1-A1.

[3] de Souza Batista CM, Yang RZ, Lee MJ, Glynn NM, Yu DZ, Pray J, Ndubuizu K, Patil S, Schwartz A, Kligman M, Fried SK, Gong DW, Shuldiner AR, Pollin TI, McLenithan JC (2007): Omentin plasma levels and gene expression are decreased in obesity. Diabetes ;56:1655-61.

[4] Moreno-Navarrete JM, Catalán V, Ortega F, Gómez-Ambrosi J, Ricart W, Frühbeck G, Fernández-Real JM. (2010): Circulating omentin concentration increases after weight loss. Nutr Metab (Lond) 7:27.

[5] Brunetti L, Orlando G, Ferrante C, Recinella L, Leone S, Chiavaroli A, Di Nisio C, Shohreh R, Manippa F, Ricciuti A, Vacca M. (2013): Orexigenic effects of omentin-1 related to decreased CART and CRH gene expression and increased norepinephrine synthesis and release in the hypothalamus. Peptides. doi:pii: S01969781(13)00112-5. 10.1016/j.peptides.2013.03.019 
[6] Temple, R.C.; Clark, P.M. and Hales, C.N. (1992): Measurement of insulin secretion in type 2 diabetes: problems and pitfalls. Diabetic Medicine 9: 503-512.

[7] Tietz, N.W.; Cook, T. and McNiven, M.A. (1995): Clinical Guide to Laboratory Tests, W.B. Saunders, Co., Philadelphia, 509-512.

[8] Sun, G.; Bishop, J.; Khalili, S.; Vasdev, S.; Gill, V.; Pace, D.; Fitzpatrick, D.; Randell, E.; Ya- Xie, G. and Zhang, H. (2007): Serum visfatin concentrations are positively correlated with serum triacylglycerols and down-regulated by overfeeding in healthy young men. Am J Clin Nutr ; 85:399404.

[9] Nauck, M; Marz, W. and Jarausch, J. (1997): Multicenter evaluation of a homogenous assay for HDL-Cholesterol without sample pretreatment Clin Chem., 43: 1622-1629.

[10] Fossati, P. (1982): Principle Lab. Clin Chem., 28: 2077-2079.

[11] Friedewald, W. T.; Levy, R.I. and Fredrickson, D.S., (1972): Estimation of the concentration of low-density lipoprotein cholesterol in plasma, without use of the preparative ultracentrifuge. Clin Chem., 18: 499-502.

[12] Novelli, E.; Diniz, Y.; Galhardi, C.; Ebaid, G.; Rodrigues,H.; Mani, F.; Fernandes,A.; Cicogna, A. and Novelli Filho, J.(2007): Anthropometrical parameters and markers of obesity in rats Laboratory Animals Ltd. Laboratory Animals 41, $111-119$

[13] Shan-ShanWu, Qiu-Hua Liang, Yuan Liu, RongRong Cui, Ling-Qing Yuan, and Er-Yuan Liao (2013): Omentin-1 Stimulates Human Osteoblast Proliferation through PI3K/Akt Signal Pathway. International Journal of Endocrinology. Volume 2013, Article ID 368970, 6 pages.

[14] Greulich S, Chen WJ, Maxhera B, Rijzewijk LJ, van der Meer RW, Jonker JT, Mueller H, de Wiza DH, Floerke RR, Smiris K, Lamb HJ, de Roos A, Bax JJ, Romijn JA, Smit JW, Akhyari P, Lichtenberg A, Eckel J, Diamant M, Ouwens DM. (2013): Cardioprotective properties of omentin-1 in type 2 diabetes: evidence from clinical and in vitro studies. PLoS One. (3):e59697. doi: 10.1371/journal.pone.0059697.

[15] Kalisz M, Baranowska B, Bik W. (2012): Do novel adipokines play a causative or only modulating role in the pathogenesis of obesity and metabolic disorders? Neuro Endocrinol Lett.;33(1):11-5.

[16] Tan BK, Pua S, Syed F, Lewandowski KC, O'Hare JP, Randeva HS. (2008): Decreased plasma omentin-1 levels in type 1 diabetes mellitus. Diabet Med 25:1254-1255.

[17] Derosa G, Cicero AF, Carbone A, Querci F, Fogari E, D'Angelo A, Maffioli P. (2013): Results from a 12months, randomized, clinical trial comparing an olmesartan/amlodipine single pill combination to olmesartan and amlodipine monotherapies on blood pressure and inflammation. Eur J Pharm Sci. 30;51C:26-33. doi: 10.1016/j.ejps.2013.08.031. [Epub ahead of print]

[18] Derosa G, Carbone A, D'Angelo A, Querci F, Fogari E, Cicero AF, Maffioli P. (2013): Variations in Inflammatory Biomarkers Following the Addition of Sitagliptin in Patients with Type 2 Diabetes not Controlled with Metformin. Intern Med. 52(19):2179-87. Epub 2012 Mar 1.

[19] Derosa G, Ragonesi PD, Carbone A, Fogari E, D'Angelo A, Cicero AF, Maffioli P. (2013): Evaluation of the positive effects on insulinresistance and $\beta$-cell measurements of vildagliptin in addition to metformin in type 2 diabetic patients. Pharmacol Res. 73:20-6. doi: 10.1016/j.phrs.2013.04.005. Epub 2013 Apr 26.

[20] Jialal I, Devaraj S, Kaur H, Adams-Huet B, Bremer AA. (2013): Increased chemerin and decreased omentin-1 in both adipose tissue and plasma in nascent metabolic syndrome. J Clin Endocrinol Metab. 98(3):E514-7. doi: 10.1210/jc.2012-3673. Epub 2013 Jan 9

[21] Shibata R, Ouchi N, Takahashi R, Terakura Y, Ohashi K, Ikeda N, Higuchi A, Terasaki H, Kihara S, Murohara T. (2012): Omentin as a novel biomarker of metabolic risk factors. Diabetol Metab Syndr. 26;4(1):37. doi: 10.1186/1758-5996-4-37. 


\section{دراسة عن تأثير الأومنتين في أيض الجلوكوز و الدهون في الفئران الطبيعة و المصابة بمرض السكري} أحدد بهاء الدين عبد الله، محد سيل أحدد زمزم، عزة عبدالرحمن مجاهد، صفية إبراهيم إسعاعيل

المقدمة: هرمون الاومنتين من الهرمونات المكتشفة حديثا سنة 2003 والذي سمي بهذا الاسم لأنه يفرز من النسيج الدهني الحشوي في الفئران

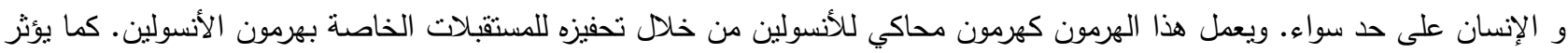

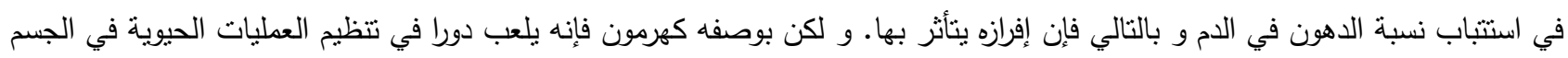

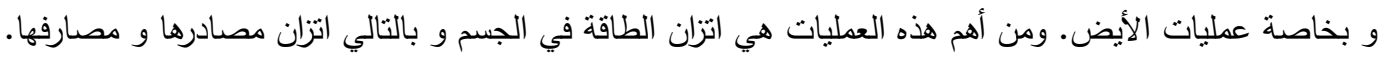
الهـف من الدراسة: صمم هذا العمل لدراسة تأثير هرمون الاومنتين على انضباط مستوى سكر الجلوكوز و الدهون في الدم في حيوانات التجارب الطبيعية بالإضافة إلى حيوانات التجارب المصابة بداء السكري. مواد و طرق البحث : أجري البحث على سنين (60) من ذكور الفئران البيضاء البالغة قسمت إلى ثلاثة مجموعات: المجموعة الأولى مجموعة ضابطة تحقن بماء مقطر، المجموعة الثانية مجموعة تحقن بهرمون الاومنتين، المجموعة الثالثة مجموعة تتم تغذيتها بغذاء عالي الدهون لمدة اثثي عشر أسبوعا و ذلك لإحداث مرض السكري المصاحب للسمنة ثم تقسم هذه المجموعة إلى أربعة مجموعات: مجموعة (3 أ): مجموعة مصابة بمرض السكري، مجموعة (3 - ب): مجموعة مصابة بمرض السكري و تحقن بهرمون الاومنتين ، مجموعة (3 - ج): مجموعة مصابة بمرض السكري و تحقن بهرمون الأنسولين ، مجموعة (3 - د): مجموعة مصابة بمرض السكري و تحقن بهرمون الأنسولين و هرمون الاومنتين. تم حقن الفئران لمدة أسبوع وفي نهاية الأسبوع تم قياس المتغيرات الثالية: مستوى السكر في الدم ، مستوى هرمون الأنسولين في الدم ، مؤشر هوما لقياس مقاومة الانسولين ، مؤشر هوما لقياس وظيفة خلايا بيتا في البنكرياس ، مستوى الدهون في الدم ، مؤشر كتلة الجسم و محيط

نتائج الدراسة : سجلت الدراسة الحالية حدوث انخفاض ذي دلالة إحصائية في مستوى السكر في الدم في الحيوانات المصابة بمرض السكري

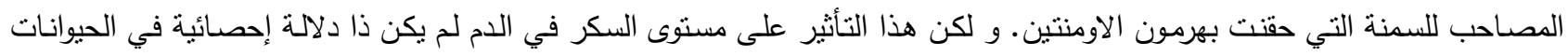

و سجلت الدراسـة الحالية أيضا حدوث انخفاض ذي دلالة إحصائية في مؤشر مقاومة الانسولين مصحوبا بزيادة ذات دلالة احصائية في

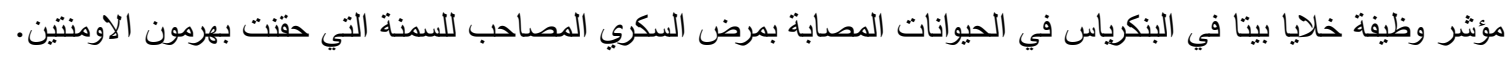

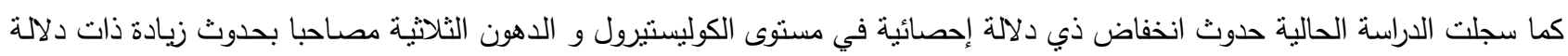



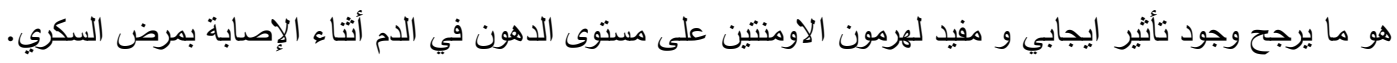

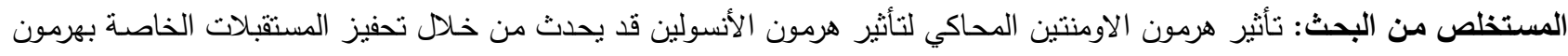

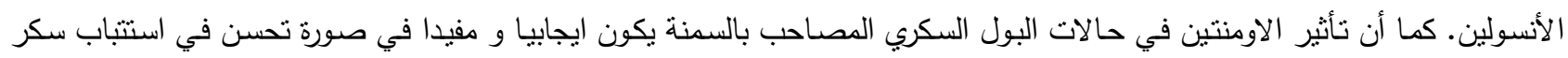

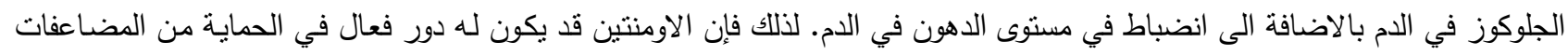
المصاحبة لمرض البول السكري المصاحب بالسمنة. 